\title{
Population ecology of vervet monkeys in a high latitude, semi-arid riparian woodland
}

\begin{tabular}{|c|c|}
\hline $\begin{array}{l}\text { Authors: } \\
\text { Graham Past } \\
\text { Leslie R. Brov } \\
\text { Stefan Kienzl } \\
\text { Andrea Fuller } \\
\text { Louise Barret } \\
\text { S. Peter Henz }\end{array}$ & $\begin{array}{l}\operatorname{nak}^{1,2} \\
\mathrm{n}^{2} \\
2,3\end{array}$ \\
\hline \multicolumn{2}{|c|}{$\begin{array}{l}{ }^{1} \text { Department of Psychology, } \\
\text { University of Lethbridge, } \\
\text { Canada }\end{array}$} \\
\hline \multicolumn{2}{|c|}{$\begin{array}{l}{ }^{2} \text { Applied Behavioural Ecology } \\
\text { and Ecosystems Research } \\
\text { Unit, University of South } \\
\text { Africa, South Africa }\end{array}$} \\
\hline \multicolumn{2}{|c|}{$\begin{array}{l}{ }^{3} \text { Department of Geography, } \\
\text { University of Lethbridge, } \\
\text { Canada }\end{array}$} \\
\hline $\begin{array}{l}{ }^{4} \text { School of } \mathrm{Ph} \\
\text { University of } \\
\text { Witwatersrar }\end{array}$ & $\begin{array}{l}\text { siology, } \\
\text { he } \\
\text {, South Africa }\end{array}$ \\
\hline \multicolumn{2}{|c|}{$\begin{array}{l}\text { Correspondence to: } \\
\text { Peter Henzi }\end{array}$} \\
\hline \multicolumn{2}{|c|}{$\begin{array}{l}\text { Email: } \\
\text { peter.henzi@uleth.ca }\end{array}$} \\
\hline \multicolumn{2}{|l|}{$\begin{array}{l}\text { Department } \\
\text { University of } \\
\text { Lethbridge, A } \\
\text { Canada }\end{array}$} \\
\hline \multicolumn{2}{|c|}{$\begin{array}{l}\text { Received: } 25 \text { Feb. } 2012 \\
\text { Accepted: } 20 \text { Aug. } 2012 \\
\text { Published: } 20 \text { Feb. } 2013\end{array}$} \\
\hline \multicolumn{2}{|c|}{$\begin{array}{l}\text { How to cite this article: } \\
\text { Pasternak, G., Brown, } \\
\text { L.R., Kienzle, S., Fuller, A., } \\
\text { Barrett, L. \& Henzi, S.P., } \\
\text { 2013, 'Population ecology } \\
\text { of vervet monkeys in a high } \\
\text { latitude, semi-arid riparian } \\
\text { woodland', Koedoe 55(1), } \\
\text { Art. \#1078, 9 pages. http:// } \\
\text { dx.doi.org/10.4102/koedoe. } \\
\text { v55i1.1078 }\end{array}$} \\
\hline \multicolumn{2}{|c|}{$\begin{array}{l}\text { Copyright: } \\
\text { (C) 2013. The Authors. } \\
\text { Licensee: AOSIS } \\
\text { OpenJournals. This work } \\
\text { is licensed under the } \\
\text { Creative Commons } \\
\text { Attribution License. }\end{array}$} \\
\hline \multicolumn{2}{|l|}{ Read online: } \\
\hline 口保口 & $\begin{array}{l}\text { Scan this QR } \\
\text { code with your } \\
\text { smart phone or } \\
\text { mobile device } \\
\text { to read online. }\end{array}$ \\
\hline
\end{tabular}

Narrow riparian woodlands along non-perennial streams have made it possible for vervet monkeys to penetrate the semi-arid karoo ecosystem of South Africa, whilst artificial water points have more recently allowed these populations to colonize much more marginal habitat away from natural water sources. In order to better understand the sequelae of life in these narrow, linear woodlands for historically 'natural' populations and to test the prediction that they are ecologically stressed, we determined the size of troops in relation to their reliance on natural and artificial water sources and collected detailed data from two river-centred troops on activity, diet and ranging behaviour over an annual cycle. In comparison to other populations, our data indicate that river-centred troops in the karoo were distinctive primarily both for their large group sizes and, consequently, their large adult cohorts, and in the extent of home range overlap in what is regarded as a territorial species. Whilst large group size carried the corollary of increased day journey length and longer estimated interbirth intervals, there was little other indication of the effects of ecological stress on factors such as body weight and foraging effort. We argue that this was a consequence of the high density of Acacia karroo, which accounted for a third of annual foraging effort in what was a relatively depauperate floristic habitat. We ascribed the large group size and home range overlap to constraints on group fission.

Conservation implications: The distribution of group sizes, sampled appropriately across habitats within a conservation area, will be of more relevance to management than average values, which may be nothing more than a statistical artefact, especially when troop sizes are bimodally distributed.

\section{Introduction}

Models that derive the limits of group size from the constraining effects of environmental variables on activity schedules have been very successful in predicting the distribution of social primates (Dunbar 1996, Korstjens, Verhoeckx \& Dunbar 2006). Such modelling has value, not only for recreating a species' evolutionary biogeography, but also for simulating the future consequences of climate change. Nevertheless, by necessity, these models operate at a relatively coarse spatial scale and are not therefore able to discern the local presence or absence of species. A very good example of this is the inability of a recent activity budget model to detect the presence of vervet monkeys (Cercopithecus aethiops) in the semi-arid karoo biome of South Africa (Figure 5 in Willems \& Hill 2009), whereas they have had a historically documented presence since at least the 18th century (Skead 1987) and are, in fact, now regionally widespread.

Although the provision of artificial point water sources for livestock has increased their distribution, local vervet monkey populations in the karoo have been confined historically to narrow strips of Acacia karroo woodland along non-perennial rivers and streams in otherwise inhospitable open country. In this regard, then, the failure of the activity budget model to predict their presence is a consequence only of the fact that these riparian woodlands are, in effect, anomalous features in the larger landscape. Nevertheless, they are very important components of the local ecosystem, both as refugia and corridors (Puth \& Wilson 2001), especially in the context of increasing temperatures and decreasing rainfall in this part of South Africa (Hoffman et al. 2009).

Consequently, the general research question we address here is directed at the local viability of these vervet populations and the consequences of life for an obligate social mammal restricted to these narrow riparian strips, where migration pathways are severely constrained (see also Isbell, Cheney \& Seyfarth 2002) and the effects of drought are exacerbated by both high summer temperatures and very low winter ones. Taken in conjunction with the modelled expectation that vervet monkeys should not be found in the karoo, we test the obvious prediction that existing natural populations should exhibit clear signs of ecological stress and be susceptible to extirpation. 
We present data on the demographic and ecological characteristics of one such population, not only to describe its general characteristics, but also to provide a qualitative test of the prediction by comparison with available data from vervet populations elsewhere.

\section{Research method and design Study area}

The data come from an ongoing study of a vervet monkey population in the Samara Private Game Reserve, Eastern Cape Province, South Africa $\left(32^{\circ} 22^{\prime} \mathrm{S}, 24^{\circ} 52^{\prime} \mathrm{E}\right.$, Figure 1). The reserve comprises 27000 ha of mountains and nama-karoo grassland transected by the Milk River and its tributaries. Our study site is located in the north of the reserve where the river, which flows only intermittently, has not been dammed and where the monkeys have no access to artificial water sources. Such point sources of water have been established away from the river and generally have vervet groups associated with them. The area receives a declining average of $330 \mathrm{~mm}$ rain per annum (wet season, October-March; dry season, AprilSeptember) and experiences a mean maximum temperature of $27^{\circ} \mathrm{C}$ and a mean minimum temperature of $10^{\circ} \mathrm{C}$. The coldest month is July when snow falls on the surrounding mountains (mean minimum, $4{ }^{\circ} \mathrm{C}$ ), whilst December and January are the hottest (mean maximum, $34^{\circ} \mathrm{C}$ ). In addition to a variety of ungulates, the reserve has an established predator guild. Animals either observed to prey on the study population, or to elicit alarm calling, include cheetah (Acinonyx jubatus), caracal (Caracal caracal), black-backed jackal (Canis mesomelas), martial eagle (Polemaetus bellicosus), Verreaux's eagle (Aquila verreauxii) and Cape eagle owl (Bubo capensis). Whilst there are no large constrictors in the region, venomous snakes were also a confirmed source of mortality.

\section{Vegetation surveys}

We stratified the study site into physiognomic-physiographic units using a 1:12 000 aerial photograph and located 35 sample plots of $400 \mathrm{~m}^{2}$ on a randomly stratified basis within the various identified units, where the number of plots was determined by each unit's area. We conducted BraunBlanquet vegetation and habitat surveys in each of the sample plots during March 2010 to define plant communities by recording all plant species in each of the plots and estimating the percentage cover for the tree, shrub, and herbaceous layers using the modified 9-degree Braun-Blanquet sampling scale (Kent \& Coker 2008). This method is used to define plant communities by grouping sets of vegetation samples on the basis of their floristic attributes (Barbour, Burk \& Pitts 1987). We recorded all plant species present in each of the plots and estimated the percentage cover for the tree,

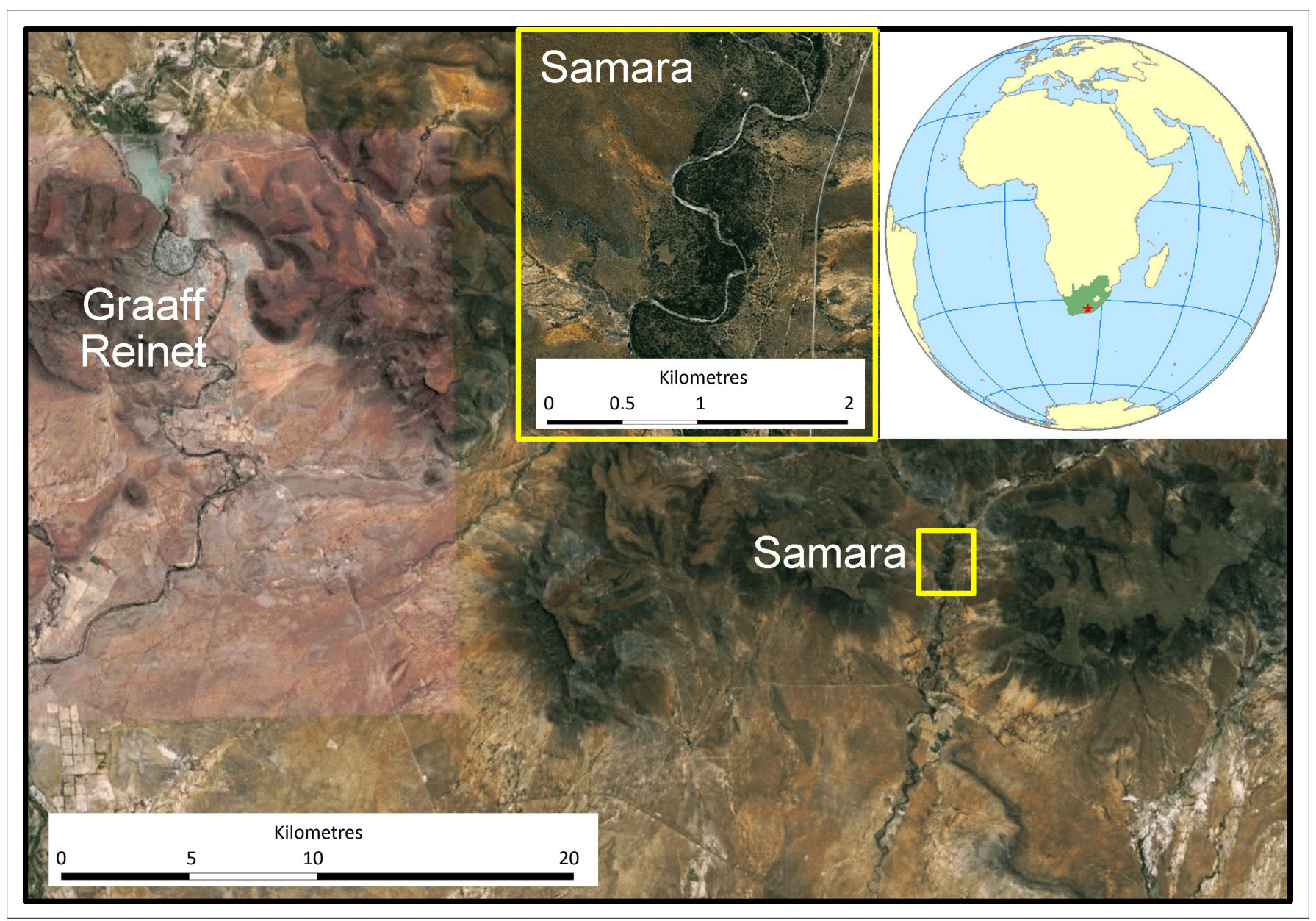

Source: Aerial photograph courtesy of Google Earth

FIGURE 1: The location of the general study area within South Africa and in relation to the town of Graaff-Reinet, where the rectangle indicates the study site enlarged in the inset. 
shrub, and herbaceous layers using the Braun-Blanquet cover abundance scale. We first analysed the floristic data using the multivariate classification programme, Two-way Indicator Species Analysis (TWINSPAN) (Tichý et al. 2007) to obtain a statistically derived approximation of the main plant communities. We then refined this classification by applying Braun-Blanquet procedures (Brown \& Bredenkamp 1994).

\section{Group counts}

Two or more observers simultaneously counted vervet monkey groups during 2009 and 2010, either from vehicles or on foot at distances of $10 \mathrm{~m}-100 \mathrm{~m}$. All groups were counted at least twice and their locations specified using a Global Positioning System (GPS) recorder. Most groups were located early in the mornings at their sleeping sites and counted as they departed. This allowed us to obtain repeated, reliable counts of smaller troops in open country away from the river. Counts of groups with home ranges centred on the river were made as they crossed roads or dry river-beds. Apart from the two study troops, for which exact troop size records have been kept, counts of such river-centred groups are best regarded as conservative estimates of troop size.

\section{Activity, diet and ranging}

Data on the diurnal activity schedules and diet of adult female monkeys were obtained over ten months, from February to November, during 2010. They came from two habituated groups (RBM, RST) using scan samples (Altmann 1974) taken over a $10 \mathrm{~min}$ period every $30 \mathrm{~min}$ during all-day follows $\left(N_{2010}=36898\right.$ records). Our data indicate no systematic bias in the number of records across the day and we derive percentages from overall frequencies. All animals could be followed at distances of one to five metres. During each scan period, the activity of all visible animals was assigned to one of four mutually exclusive states - Foraging, Moving, Socialising or Resting - and recorded using an electronic data logger. When animals were foraging, we also recorded both the food species and the part eaten. At the end of each scan period, we took a GPS reading from the troop's estimated centre. These readings, together with additional data from January and December 2010, were used to derive both day journey lengths and, subsequently, home range areas for each of the two troops. After importing all relevant GPS data, we derived day journey length and travel velocities using both the ET GeoWizards tool (Tchoukanski 2010) and ArcGIS. We applied the Home Range Tools (HRT) for ArcGIS (Rodgers et al. 2007) to determine the minimum convex polygon (MCP) estimates of both the home range size (99\% MCP) and each troop's core area (50\% MCP), using an adaptive kernel with a bandwidth of $25 \mathrm{~m}$. Home range overlaps were calculated from GPS readings taken of the location of all other troops when these were observed in areas used by the two study troops, where accuracy was ensured by taking the readings from the observed locations once the other troops had moved away.

In addition to these behavioural data, records have been kept of all births, deaths, immigration and emigration since November 2008.

\section{Body mass}

We obtained body mass data from adults of both sexes that were anaesthetised for the surgical implantation of temperature loggers (University of the Witwatersrand Animal Ethics Screening Committee - Clearance Number 2010/41/04).

\section{Statistical analysis}

All tests were conducted with the JMP 9 statistical package (SAS Institute 2007), with alpha set at 0.05.

\section{Results \\ Vegetation structure}

The area has relatively low species richness, with 124 different plant species identified within the home ranges of the two study vervet troops. We identified three plant communities that could be grouped into two major structural units: (1) open dwarf shrubland on the slightly higher lying and drier areas, which continues into (2) dense A. karroo woodland along the seasonal river (Figure 2).

The largest plant community - Lycium oxycarpum-A. karroo woodland - occurs along the river and floodplain and is dominated by the trees, A. karroo and L. oxycarpum, with the tree Rhus lancea and the tall shrub Rhus longispina also

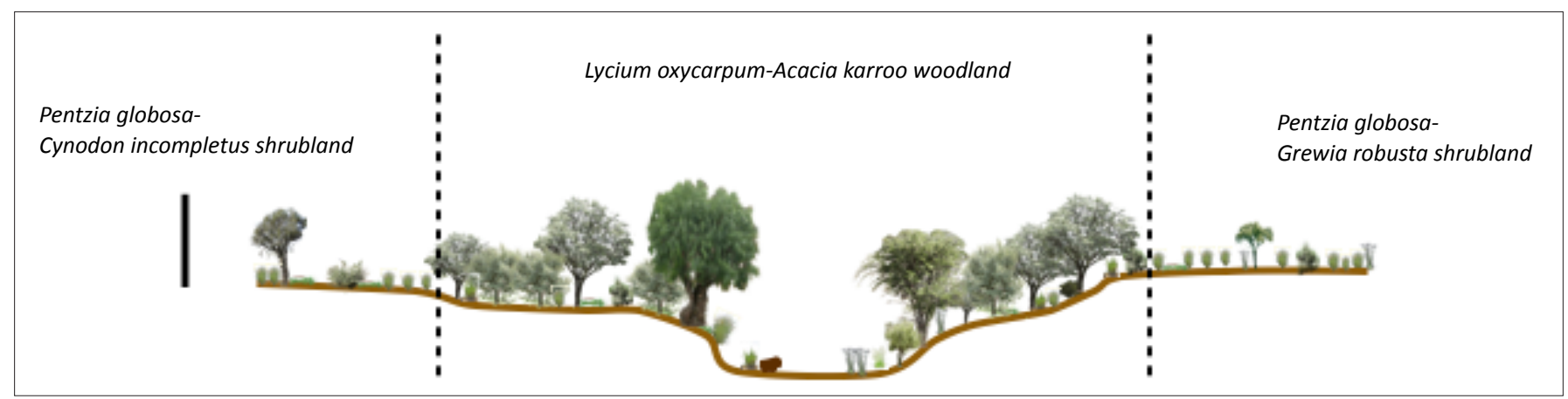

The vertical bar on the left is $5 \mathrm{~m}$ high.

FIGURE 2: Cross-sectional vegetational profile of the study area, indicating the three main communities. 
prominent. Large single individuals $(>6 \mathrm{~m}$ ) of the pepper bark tree (Schinus molle) are scattered along the river bank. The woody species range in height from $1 \mathrm{~m}$ to $5 \mathrm{~m}$ and form dense canopies that cover up to $80 \%$ of the area. The herbaceous layer is dominated by the palatable grass, Panicum maximum, and the pioneer grass, Cynodon incompletus. The two communities that comprise dwarf shrubland - Pentzia globosa-Grewia robusta shrubland to the west and P. globosaC. incompletus shrubland to the east - extend on the higherlying areas adjacent to the Acacia woodland and are both relatively open areas dominated by the dwarf shrub, $P$. globosa, and the tall shrub, R. longispina. Whereas the woodland is still in very good condition, both shrubland communities are degraded - a consequence of grazing in the $P$. globosa-G. robusta shrubland and cultivation in the P. globosa-C. incompletus shrubland prior to 1998.

\section{Population structure}

We obtained repeated, reliable counts from 29 troops. This gave us a mean troop size of 26.62 ( \pm 18.11 s.d.) for the population. Troops were distinguished, however, by whether their ranges were centred on the river or whether their source of water was artificial and maintained by humans. River troops $(N=15)$ had a significantly larger mean size $(40.13 \pm 15.53$ s.d. $)$ than troops relying on human-provided water $(N=14$, Mean $=12.14 \pm 3.23$ s.d., Analysis of variance [ANOVA]: $\mathrm{F}_{1.27}=43.57, P<0.0001$, Figure 3). The sizes of the two study troops, occupying adjacent home ranges, were $N_{\mathrm{RBM}} \approx 48$ and $N_{\mathrm{RST}} \approx 72$ respectively. The modal adult sex ratio (male $[\mathrm{M}]$ or female $[\mathrm{F}])$ was 0.67 for $\mathrm{RBM}\left(N_{\text {MALES }}=10\right.$, $\left.N_{\text {FEMALES }}=15\right)$ and 0.43 for $\operatorname{RST}\left(N_{\text {MAleS }}=10, N_{\text {feMAles }}=23\right)$.

\section{Inter-birth intervals}

We recorded 65 births over 36 months $\left(N_{\mathrm{RBM}}=30 ; N_{\mathrm{RST}}=35\right)$, with an overall birth rate of 0.57 infants/female/year (Birth rate $_{\mathrm{RBM}}=0.67$; Birth rate $_{\mathrm{RST}}=0.5$ ), allowing us to estimate an inter-birth interval of 21 months (RBM = 17.9 months; RST $=24$ months).

\section{Day journey length}

We analysed 295 entire day journeys $\left(N_{\mathrm{RBM}}=138, N_{\mathrm{RST}}=157\right)$. The mean distance travelled by RBM was $2806.3 \mathrm{~m}$ (Range: $1013 \mathrm{~m}-5229 \mathrm{~m}$ ) whilst that for RST was $2353.6 \mathrm{~m}$ (Range: $912 \mathrm{~m}-4320 \mathrm{~m}$ ). The data come from a year of low rainfall when both study troops frequently visited a distant water hole $(N=100)$ during periods when there was no water available in their core areas (McDougall et al. 2010). As this increased the mean day journey by more than $500 \mathrm{~m}$, we therefore ran a full-factorial ANOVA with Troop Identity, Season Wet or Dry and Water Hole Visits (Yes or No) as factors and day journey length as the dependent variable. The whole model was significant $\left(\mathrm{F}_{7287}=11.22\right.$, Adj. $\left.R^{2}=0.195, P<0.001\right)$ and there were significant main effects for Troop Identity $\left(\mathrm{F}_{1.1}=15.1, P<0.001\right)$, Season $\left(\mathrm{F}_{1.1}=4.5, P<0.05\right.$, Mean distance $_{\text {Dry }}=2760.3 \mathrm{~m}$, Mean distance ${ }_{\text {Wet }}=2387.8 \mathrm{~m}$ ) and for Water Hole Visits $\left(\mathrm{F}_{1.1}=32.75, P<0.0001\right.$,
Mean distance $_{\text {Yes }}=2972.3 \mathrm{~m}$, Mean distance $\left._{\mathrm{No}}=2431.97\right)$. The only significant interaction was for Season Water Hole Visit $\left(\mathrm{F}_{1.1}=4.4, P<0.05\right)$, with visits to the water hole increasing day journey length in the wet season.

\section{Home range size and population density}

We used the day journeys to estimate the annual home range sizes for the two study troops (Figure 4). In the habituated group RBM's 99\% MCP covered an area of 176.1 ha of which the four discrete core areas constituted 10.45 ha. They shared $23 \%$ of their home range with five other troops. The habituated group RST used 63.7 ha over the same period, with a single core area of 7.42 ha. They shared $86 \%$ of their home range with 4 other troops. The larger home range of the smaller group is likely to be due to their having no other troops on their western boundary. On the assumption that overlap areas were shared equally by the study troops and their neighbours (cf. Whiten, Byrne \& Henzi 1987), the data from RBM generate a population density of 30.79 animals $/ \mathrm{km}^{2}$, whilst the value for RST is 202.24 animals $/ \mathrm{km}^{2}$. Combining the data for RBM and RST and taking account of the 40.7 ha overlap between their two home ranges, gave a composite population density estimate of 54.68 animals $/ \mathrm{km}^{2}$. We estimated the defendability of these home ranges (A) in relation to the average day journey length (d), using Mitani and Rodman's (1979) Defendability index (D), where D = d/d' and $\mathrm{d}^{\prime}=4 \mathrm{~A} / \Pi^{0.5}$, where $\mathrm{D} \geq 1$, home ranges are assumed to be defendable. The values for Samara were computed as $\mathrm{D}_{\text {RBM }}=1.05 ; \mathrm{D}_{\mathrm{RST}}=1.44$.

\section{Activity}

The relative allocation of time by the females of the two troops to the four activity categories is provided in Table 1.

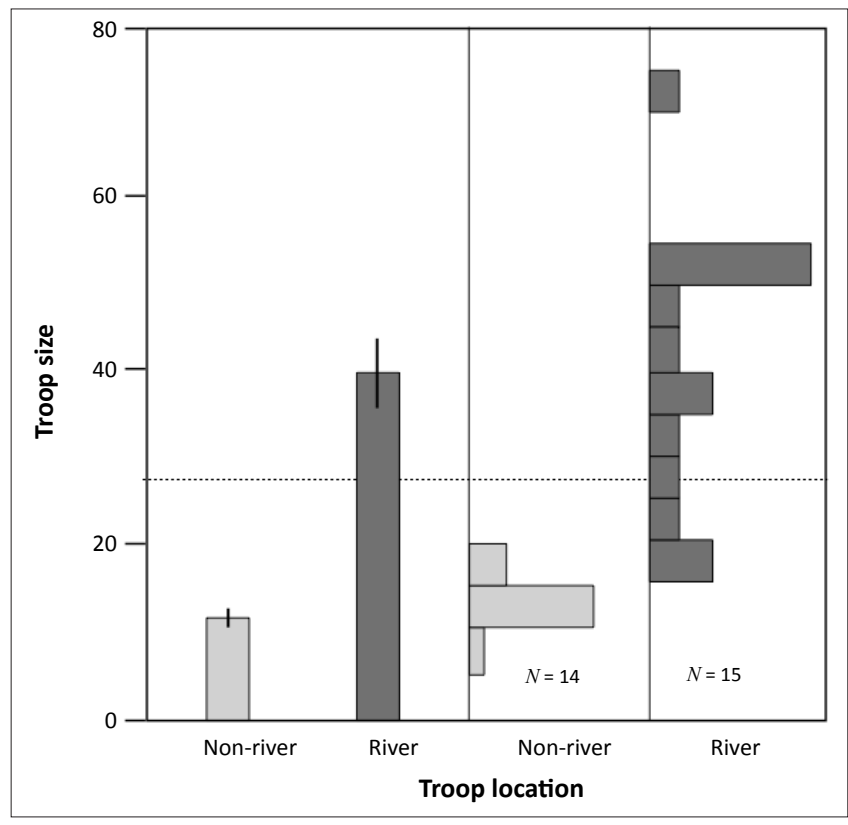

The horizontal bars indicate the frequency distribution of troop size. The dotted line is the overall mean troop size.

FIGURE 3: Mean troop size +/- 1 s.d. and distribution for non-river and rivercentred troops. 


\section{Diet}

The animals foraged on 26 different plant species as well as fungi and a number of different insects, of which grasshoppers and termites were eaten most frequently (Appendix 1). The five most frequent items in the diet accounted for $68.7 \%$ of annual foraging effort. Acacia karroo products alone accounted for $33.8 \%$ of all foraging records and were used consistently across the 10 months (Figure 5).

\section{Body mass}

Adult males weighed $5.93 \mathrm{~kg}+/-0.42 \mathrm{s.d} .(N=9)$ and females weighed $3.3 \mathrm{~kg} .+/-0.3 \mathrm{s.d} .(N=13)$. These are compared to values from other populations in Figure 6.

\section{Ethical considerations}

The behavioural data collection was conducted under the terms of reference of Animal Welfare Protocol 0702 (University of Lethbridge) and clearance for the body mass measurements was obtained from by the University of the Witwatersrand Animal Ethics Screening Committee (Clearance Number 2010/41/04).

\section{Discussion}

Karoo vervet troops whose ranges centre on local rivers are significantly larger than those found away from rivers. Colonisation of areas away from these rivers is made possible by the presence of artificial water points that therefore provide a population sink for large river troops, but carries the corollary that the animals are confronted by habitat that is both naturally less productive and currently degraded. This would explain their small troop sizes and suggests a vulnerability to downturns in local environmental conditions. Indeed, at least three non-river troops that were monitored in 2009 as part of the census were no longer locatable by the end of 2010, over which period the local drought had worsened. Whilst the presence of water means that their disappearance was likely to have been associated with a decline in food availability, it is not known whether they suffered extirpation or had returned to the river and fused with troops there, as observed by Isbell, Cheney and Seyfarth (1991).

The absence of artificial water points along the Milk River and the relative lack of degradation of the riparian habitat itself suggests that river-centred troops constitute the 'natural' regional population and can therefore be used to characterise the response of the species to these narrow habitable corridors that run through an otherwise inhospitable landscape. Perhaps the most surprising finding in this regard, given the inability of the activity budget models to predict their presence in the region, is that they are not a marginal population but an apparently flourishing one, with most parameter values used to determine population viability well within the range of those reported from other study sites (Table 2; Figure 6). There are two values, however, that might, at first glance, be assumed to indicate ecological
TABLE 1: The annual percentage of adult scan samples allocated to each of four activities.

\begin{tabular}{lllll}
\hline Troop & Forage & Move & Rest & Social \\
\hline RBM & 31.8 & 23.9 & 33.1 & 10.4 \\
RST & 31.6 & 25.2 & 32.8 & 9.5 \\
\hline
\end{tabular}

RBM, RST, habituated groups.

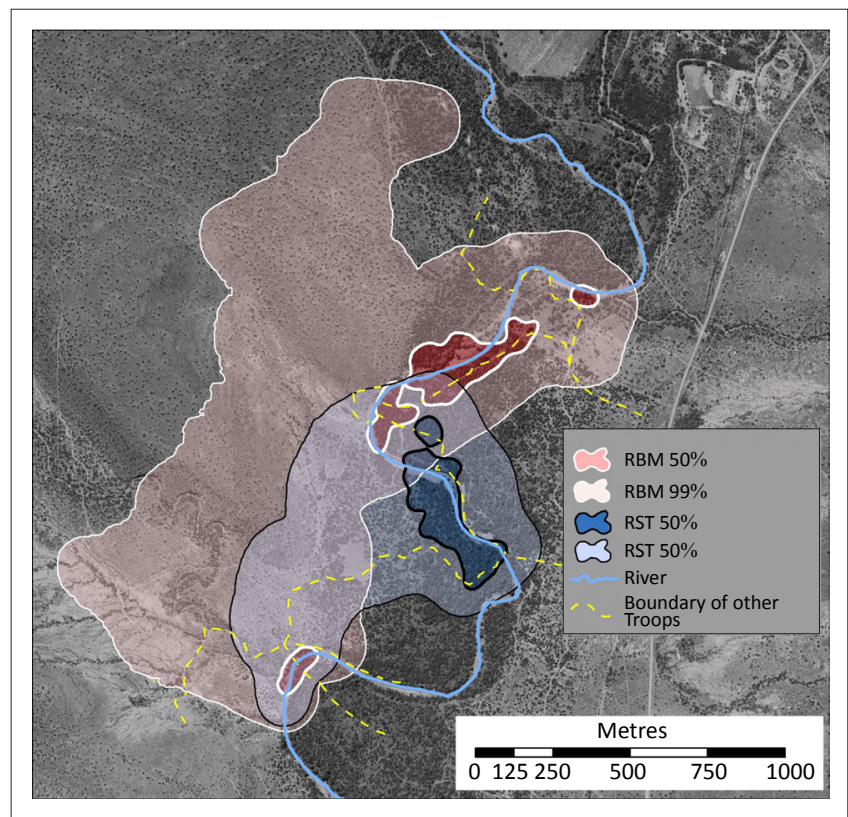

RBM, RST, habituated groups.

FIGURE 4: Home ranges of the study troops, indicating core areas and overlap.

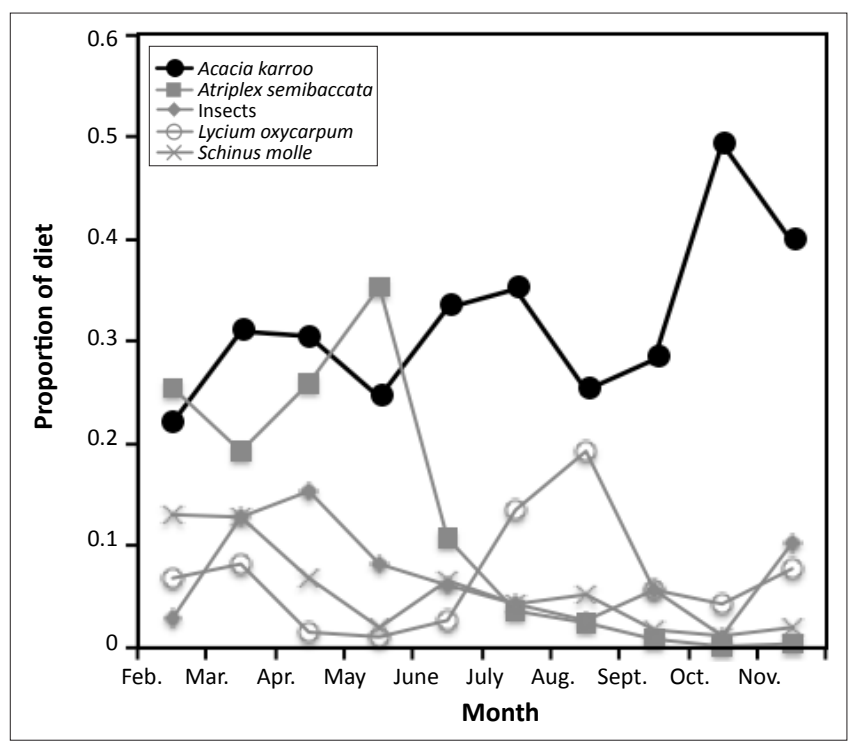

FIGURE 5: Contributions of the five most commonly used food sources to monthly foraging effort.

stress. The first is the longer interbirth interval in comparison to those reported from the long-term study at Amboseli and the second is the longer day journeys undertaken by our two study groups. Although data from more years will be valuable, both may reasonably be explained in terms of increased group size: the associated intragroup competition leads to lower reproductive rates, whilst larger groups need to cover more ground in order to forage (Borries et al. 2008; Clutton-Brock \& Harvey 1977). The latter is corroborated by 
data from 12 troops (Barrett 2009; Willems 2009, this study) that indicate a positive correlation between troop size and day journey length $\left(r_{\mathrm{s}}=0.78, N=12, P<0.001\right)$.

What therefore needs to be explained are the distinctively large size of river-centred groups and - given that vervet

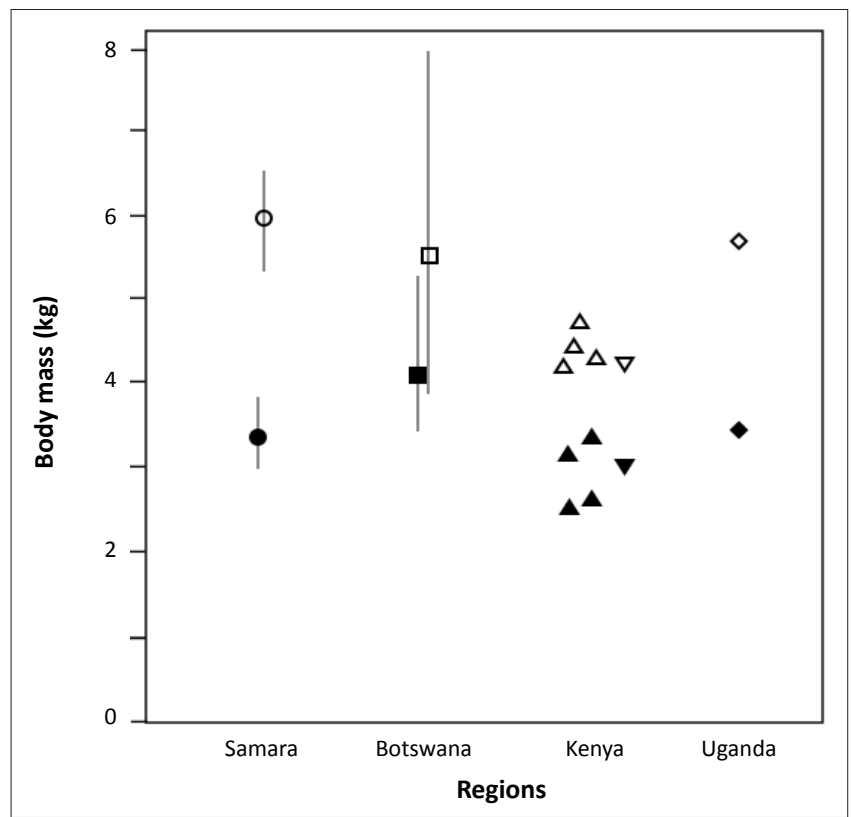

Source: Data for Botswana squares from Skinner and Chimimba (2005); Kenya triangles from Kagira et al. (2007) and Turner et al. (1997); Uganda diamonds from Bolter and Zihlman (2003)

Note: Please see the full reference list of the article, Pasternak, G., Brown, L.R., Kienzle, S. Fuller, A., Barrett, L. \& Henzi, S.P., 2013, 'Population ecology of vervet monkeys in a high latitude, semi-arid riparian woodland', Koedoe 55(1), Art. \#1078, 9 pages. http://dx.doi. org/10.4102/koedoe.v55i1.1078.

Each symbol identifies a particular population.

Open symbols, adult males; solid symbols, adult females.

FIGURE 6: Comparison of body mass across different vervet monkey populations. Where available, standard deviations are indicated. monkeys are territorial (Struhsaker 1967) - the marked extent of home range overlap. In the absence of indications of gross ecological stress, the large troops living at high densities are clearly being sustained by the consistent availability of A. karroo products, as is true, not only for the historically high density population of vervets at Amboseli in Kenya, where Acacia xanthophloea and Acacia tortilis played much the same role (Struhsaker 1967, Lee \& Hauser 1998), but also for vervets living at lower density in the northern South Africa (Barrett 2004, 2009). At the same time, the inclusion of both insects and succulents in the diet (Pasternak 2011) buffered the animals during those periods when free-standing water was absent (McDougall et al. 2010). Whilst one might expect some broad positive relationship between group size and population density (Van Schaik 1983), three things suggest that this alone will not provide an adequate explanation for population structure at Samara. The first is that there is no indication of a correlation between density and troop size for the vervet populations in Table $2\left(r_{\mathrm{s}}=-0.09, N=11, P=0.77\right)$. The second is that mean troop size was very much smaller at a number of other sites where density was comparably high (Table 2). The third is that the time budget model for vervet troop size derived by Willems and Hill (2009) predicts a maximum ecologically tolerable troop size of 46 animals at Samara (Henzi et al. in prep.). Whereas the maximum troop size exceeded observed sizes for almost all their populations (Figure 6 in Willem \& Hill 2009), both our study troops exceeded model predictions. One possibility, of course, is that predation risk is responsible (Van Schaik 1983) but, again, for example, the Amboseli population had troops of significantly smaller size whilst being as much, if not more, at risk as the Samara river-centred troops (Pasternak 2011, Struhsaker 1967).

TABLE 2: Comparative data for different vervet monkey populations arranged by latitude.

\begin{tabular}{|c|c|c|c|c|c|c|c|c|c|c|c|c|c|c|}
\hline \multirow[t]{2}{*}{ Site } & \multicolumn{2}{|c|}{$\begin{array}{c}\text { Temperature } \\
\left({ }^{\circ} \mathrm{C}\right)\end{array}$} & \multirow[t]{2}{*}{$\begin{array}{l}\text { Rainfall } \\
(\mathrm{mm})\end{array}$} & \multicolumn{2}{|c|}{$\begin{array}{l}\text { Group } \\
\text { size }\end{array}$} & \multirow[t]{2}{*}{$\begin{array}{c}\text { Number } \\
\text { males }\end{array}$} & \multirow[t]{2}{*}{$\begin{array}{l}\text { Number } \\
\text { females }\end{array}$} & \multirow{2}{*}{$\begin{array}{l}\text { Mand } \\
\text { and } \\
\text { female } \\
\text { ratio }\end{array}$} & \multirow[t]{2}{*}{$\begin{array}{c}\text { IBI } \\
\text { (months) }\end{array}$} & \multirow{2}{*}{$\begin{array}{l}\text { Home } \\
\text { range } \\
\left(\mathrm{km}^{2}\right)\end{array}$} & \multirow{2}{*}{$\begin{array}{l}\text { Population } \\
\text { density } \\
\left(\mathrm{km}^{2}\right)\end{array}$} & \multirow{2}{*}{$\begin{array}{c}\text { Day } \\
\text { journey } \\
\text { length } \\
\text { (km) }\end{array}$} & \multirow{2}{*}{$\begin{array}{c}\% \\
\text { Home } \\
\text { range } \\
\text { overlap }\end{array}$} & \multirow[t]{2}{*}{$\begin{array}{c}\% \\
\text { Feeding }\end{array}$} \\
\hline & $\begin{array}{c}\text { Mean } \\
\text { minimum }\end{array}$ & $\begin{array}{c}\text { Mean } \\
\text { maximum }\end{array}$ & & Size & $N$ & & & & & & & & & \\
\hline This study & 10 & 27 & 330 & 40 & 15 & 10 & 19 & 0.52 & 20.6 & 1.19 & 54.7 & 2.5 & 54.5 & 31.64 \\
\hline $\begin{array}{l}\text { South Africa } \\
\text { (Loskop) }^{1}\end{array}$ & 13.5 & 26.8 & 654 & 17.6 & 6 & 3 & 3 & 1.00 & 18.7 & 0.18 & 86.4 & 0.7 & 15.7 & 33 \\
\hline $\begin{array}{l}\text { South Africa } \\
\text { (Blydeberg) }^{1}\end{array}$ & 19 & 27 & 561 & 33 & 1 & 5 & 8 & 0.63 & - & 0.77 & 42.8 & 1.34 & - & 42 \\
\hline $\begin{array}{l}\text { South Africa } \\
\text { (Lajuma) }^{3}\end{array}$ & 10.7 & 21.2 & 724 & 17.8 & 1 & 2 & 7 & 0.29 & - & 1.14 & 15.6 & 1.6 & - & 42.8 \\
\hline $\begin{array}{l}\text { Kenya } \\
\text { (Amboseli) }^{3,4,5}\end{array}$ & 13.6 & 30.4 & 330 & 24.1 & 4 & 2.5 & 5.43 & 0.46 & 17.1 & 0.42 & 66.8 & 1.18 & - & 35.4 \\
\hline $\begin{array}{l}\text { Kenya } \\
\text { (Segera) }^{4,6,7}\end{array}$ & 7.6 & 27.5 & 720 & 17.5 & 2 & 6 & 6.5 & 0.92 & - & 0.25 & 80 & 1.3 & $\sim 12$ & 23.8 \\
\hline $\begin{array}{l}\text { Kenya } \\
\text { (Lolui) }^{8}\end{array}$ & 15 & 30 & 1100 & 12.1 & 18 & 2.9 & 4.1 & 0.70 & - & - & 49.9 & - & - & - \\
\hline $\begin{array}{l}\text { Kenya } \\
\text { (Samburu) }\end{array}$ & 13.6 & 30.1 & 720 & 32.7 & 2 & 7.5 & 8.5 & 0.88 & - & 0.81 & 40.3 & 1.5 & - & 37.5 \\
\hline $\begin{array}{l}\text { Cameroun } \\
\text { (Kalamaloue) }\end{array}$ & 22 & 33 & 650 & 20 & 1 & 6 & 4 & 0.75 & - & 0.9 & 22.2 & 1.92 & 20 & 23.4 \\
\hline $\begin{array}{l}\text { Senegal } \\
\text { (Niakola Koba) }^{11}\end{array}$ & 16.3 & 39 & 954 & 19.2 & 9 & 4.5 & 7 & 0.57 & - & 1.78 & 4.3 & 1.55 & 9.6 & 44.8 \\
\hline
\end{tabular}

Source: Primary data from: 1, Barrett (2004, 2009), pers. comm.; 2, Baldellou (1992), pers. comm.; 3, Willems (2007); 4, Enstam and Isbell (2007); 5, Struhsaker (1967); 6, Isbell pers. comm.; 7, Pruetz (2009); 8, Hall and Gartlan (1965); 9, Whitten (1983); 10, Nakagawa (1999); 11, Harrison (1983, 1985)

Note: Please see the full reference list of the article, Pasternak, G., Brown, L.R., Kienzle, S., Fuller, A., Barrett, L. \& Henzi, S.P., 2013, 'Population ecology of vervet monkeys in a high latitude, semi-arid riparian woodland', Koedoe 55(1), Art. \#1078, 9 pages. http://dx.doi.org/10.4102/koedoe.v55i1.1078.

$N$, number of groups used to derive group sizes; IBI, Inter-birth intervals.

Bold indicates values for the study population that are distinctive. 
To our minds, the most viable explanation is that successful troop fission, which would offer the benefits of shorter day ranges and inter-birth intervals, requires the maintenance of access to the riparian woodland and, given that this habitat is probably saturated, this is likely to managed only rarely, fission away from the river is likely only to occur when conditions are good and when, historically, temporary water sources are available for colonisation. Interestingly, in this regard, following unusually high rainfall and improvements in resource availability during 2011, our two study troops have shown increased dispersion, with small subgroups foraging and, occasionally, sleeping independently within the home range (unpublished data). Whilst it might be argued that subgroups of this kind could simply carve out territories within the larger home range and establish themselves in this way at any time, the high $\mathrm{D}$ values mean that any putative subgroup will intersect with other troop members frequently, making it difficult to sustain coherence in membership, especially since social coherence is reduced in these large groups in any case (Henzi et al. in prep.). Given this, the unusually high levels of home range overlap appear to be a natural corollary of what is, in effect, a supersaturated riparian population, sustained by high yields from a few food sources. Under such conditions, we have found that troops do not invariably fight when they meet. If we are correct, we should record fission from these troops in phases of improved ecological conditions when the areas around artificial water points can support small groups, at least temporarily.

In summary, as at Amboseli prior to the population crash (Isbell et al. 1991), which in many regards resembles Samara most closely, the fact that Acacia provides a consistent source of food products and is abundant, allows the vervet population to reach high densities in an otherwise inhospitable environment. Unlike Amboseli and other localities, the narrow riparian distribution of Acacia and the sharp transition to marginal habitat, makes it very difficult for troops to divide into smaller units. These large rivercentred troops, in addition to any implications they carry for conservation in the region, offer an excellent opportunity to study the social dynamics of larger male and female cohorts under natural conditions and in the absence of any obvious ecological stressors.

\section{Conclusion}

The vervet population in this region of the semi-arid Karoo experiences little sign of ecological stress, and our estimates of population viability are in line with those from areas comprising more suitable vervet habitat (in terms of resource and water availability). Troops living in the riparian zone were significantly larger than those living away from the river, and were sustained by the constant availability of A. karroo. We suggest that these larger group sizes occur because group fission is inhibited by the poor quality of habitat away from the river. This gives rise to a supersaturated riparian population, in which territorial behaviour is reduced. Such groups offer an excellent opportunity to test hypotheses regarding the social dynamics and life history of vervet monkeys. Our results also emphasise that effective conservation and management practices in the Karoo should be predicated on an assessment of the distribution of group sizes, and not simply the population mean, as the bimodal distribution of large riparian groups and smaller non-riparian groups renders the latter a statistical artefact, rather than a measure that possesses biological relevance.

\section{Acknowledgements}

This project has been funded by grants from NSERC Canada, NRF South Africa and UNISA. We are most grateful to Mark and Sarah Tompkins for logistical assistance and permission to work at Samara. We thank Ria Boner, Natalie Freeman, and Tricia Rubi for help with data collection and Richard and Kitty Viljoen for many acts of kindness. Two anonymous referees provided advice that improved the manuscript substantially.

\section{Competing interests}

The authors declare that they have no financial or personal relationship(s) which may have inappropriately influenced them in writing this article.

\section{Authors' contributions}

G.P. (University of Lethbridge) collected and, with S.P.H. (University of Lethbridge) and L.B. (University of Lethbridge), analysed the behavioural data. L.R.B. (University of South Africa) undertook the vegetation survey, A.F. (University of the Witwatersrand) collected body mass data, S.P.H., G.P. and L.B. did the population survey. S.K. (University of South Africa) and G.P. undertook the spatial analyses. All authors participated in the writing of the manuscript.

\section{References}

Altmann, J., 1974, 'Observational study of behaviour: Sampling methods', Behaviour 49, 227-267.

Baldellou, M., 1992, 'Implications of the multimale troop structure in vervet monkeys (Cercopithecus aethiops pygerythrus)', PhD thesis, Department of Psychology University of Natal.

Barbour, M.G., Burk, J.H. \& Pitts, W.D., 1987, Terrestrial plant ecology, Benjamin Cummings, Menlo Park.

Barrett, A.S., 2004, 'Foraging ecology of the vervet monkey (Chlorocebus aethiops) in mixed lowveld bushveld and sour lowveld bushveld of the Blydeberg Conservancy, Northern Province, South Africa', MTech dissertation, Department Conservancy, Northern Province, South Africa', MTech
of Environmental Sciences, University of South Africa.

Barrett, A.S., 2009, 'Spatial and temporal patterns in resource dispersion and the structure of range use and coexistence in a social omnivore (Chlorocebus aethiops)', PhD thesis, Department of Environmental Sciences, University of South aethiops
Africa.

Bolter, D.R. \& Zihlman, A.L., 2003, 'Morphometric analysis of growth and development in wild-collected vervet monkeys (Cercopithecus aethiops), with implications for in wild-collected vervet monkeys (Cercopithecus aethiops), with implications for growth patterns in Old World monkeys, apes and humans',
99-110. http://dx.doi.org/10.1017/S0952836903003522

Borries, C., Larney, C., Lub, A., Ossib, K. \& Koenig, A., 2008, 'Costs of group size, lower developmental and reproductive rates in larger groups of leaf monkeys', Behavioral Ecology 19, 1186-1191. http://dx.doi.org/10.1093/beheco/arn088

Brown, L.R. \& Bredenkamp, G.J., 1994, 'The phytosociology of the southern section of the Borakalalo Nature Reserve, South Africa', Koedoe 37, 59-72. http://dx.doi. org/10.4102/koedoe.v37i2.337

Clutton-Brock, T.H. \& Harvey, P.H., 1977, 'Primate ecology and social organization', Journal of Zoology 183, 1-39. http://dx.doi.org/10.1111/j.1469-7998.1977. tb04171.x 
Dunbar, R.I.M., 1996, 'Determinants of group size in primates: A general model', Proceedings of the British Academy 88, 33-57.

Enstam, K.L. \& Isbell, L., 2007, 'The guenons (genus Cercopithecus) and their allies: Behavioral ecology of polyspecific associations', In C.J. Campbell, A. Fuentes, K.C. Mckinnon, M. Panger \& S.K. Bearder (eds.), Primates in perspective, pp. 252-274, Mckinnon, M. Panger \& S.K. Bearder
Oxford University Press, New York.

Hall, K.R.L. \& Gartlan, J.S., 1965, 'Ecology and behaviour of the vervet monkey, Cercopithecus aethiops, Lolui Island, Lake Victoria', Proceedings of the Zoological Society London 145, 37-56. http://dx.doi.org/10.1111/j.1469-7998.1965. Society Lonc

Harrison, M.J.S., 1983, 'Territorial behaviour in the green monkey, Cercopithecus sabaeus: Seasonal defense of local food supplies', Behavioral Ecology and Sociobiology 12, 85-94. http://dx.doi.org/10.1007/BF00296937

Harrison, M.J.S., 1985, 'Time budget of the green monkey, Cercopithecus sabaeus: Some optimal strategies', International Journal of Primatology 6, 351-376. http:// dx.doi.org/10.1007/BF02736383

Henzi, S.P., Barrett, L., Forshaw, N., Boner, R. \& Lusseau, D., in prep., 'Scalar social dynamics in female vervet monkey cohorts'.

Hoffman, M.T., Carrick, P.J., Gillson, L. \& West, A.G., 2009, 'Drought, climate change and vegetation response in the succulent karoo, South Africa', South African Journal of Science 105, 54-60. http://dx.doi.org/10.1590/S0038-23532009000100021

Isbell, L.A., Cheney, D.L. \& Seyfarth, R.M., 1991, 'Group fusions and minimum group sizes in vervet monkeys', American Journal of Primatology 25, 57-65. http:// dx.doi.org/10.1002/ajp.1350250106

Isbell, L.A., Cheney, D.L. \& Seyfarth, R.M., 2002, 'Why vervet monkeys (Cercopithecus aethiops) live in multimale groups', in M.E. Glenn \& M. Cords (eds.), The guenons: Diversity and adaptation in African monkeys, pp. 173-187, Kluwer Academic/ Plenum Publishers, New York.

Kaghira, J.M., Ngotho, M., Thuita, J.K., Maina, N.W. \& Hau, J., 2007, 'Hematological changes in vervet monkeys (Chlorocebus aethiops) during eight month' adaptation to captivity', American Journal of Primatology 69, 1053-1063. PMid:17294427

Kent, M. \& Coker, P., 2008, Vegetation description and analysis: A practical approach, Belhaven Press, London.

Korstjens, A.H., Verhoeckx, I.L. \& Dunbar, R.I.M., 2006, 'Time as a constraint on group size in spider monkeys', Behavioral Ecology and Sociobiology 60, 683-694. http:// dx.doi.org/10.1007/s00265-006-0212-2

Lee, P.C. \& Hauser, M.D., 1998, 'Long-term consequences of changes in territory quality on feeding and reproductive strategies of vervet monkeys', Journal of Animal Ecology 67, 347-358. http://dx.doi.org/10.1046/j.1365-2656.1998.00200.x

McDougall, P., Forshaw, N., Barrett, L. \& Henzi, S.P., 2010, 'Leaving home: Responses to water depletion by vervet monkeys', Journal of Arid Environments 74, 924-927. http://dx.doi.org/10.1016/j.jaridenv.2010.04.003

Mitani, J.C. \& Rodman, P.S., 1979, 'Territoriality: The relation of ranging pattern and home range size to defendability, with an analysis of territoriality among primate species', Behavioral Ecology and Sociobiology 5, 241-251. http://dx.doi org/10.1007/BF00293673
Nakagawa, N., 1999, 'Differential habitat utilization by patas monkeys (Erythrocebus patas) and tantalus monkeys (Cercopithecus aethiops tantalus) living sympatrically in northern Cameroon', American Journal of Primatology 49, 243-264. http:// in northern Cameroon', American Journal of Primatology 49, 243-264. http://
dx.doi.org/10.1002/(SICI)1098-2345(199911)49:3<243::AID-AJP3>3.0.CO;2-4

Pasternak, G., 2011, 'Environmental effects on group structure and vigilance in vervet monkeys', MSc thesis, Dept. of Psychology, University of Lethbridge.

Pruetz, J.D.E., 2009, The socioecology of adult female patas monkeys and vervets in Kenya, Pearson Prentice Hall, Upper Saddle River, NJ.

Puth, L.M. \& Wilson, K.A., 2001, 'Boundaries and corridors as a continuum of ecological flow control: Lessons from rivers and streams', Conservation Biology $15,21-30$.

Rodgers, A.R., Carr, A.P., Beyer, H.L., Smith, L. \& Kie, J.G., 2007, Home range tools for ArcGIS, viewed on 13 June 2011, from http://blue.lakeheadu.ca/hre/

Van Schaik, C.P., 1983, 'Why are diurnal primates living in groups?', Behaviour 87, 120-144. http://dx.doi.org/10.1163/156853983X00147

Skead, C.J., 1987, Historical mammal incidence in the Cape Province, volume $2-$ The eastern half of the Cape Province, including the Ciskei, Transkei and East Griqualand, Dept. of Nature and Environmental Conservation of the Provincial Administration of the Cape of Good Hope, Cape Town.

Skinner, J.D. \& Cimimba, C.T., 2005, The mammals of the southern African subregion, University of Pretoria Press, Pretoria.

Struhsaker, T.T., 1967, 'Ecology of vervet monkeys (Cercopithecus aethiops) in the Masai-Amboseli Game Reserve, Kenya', Ecology 48, 891-904. http://dx.doi. org/10.2307/1934531

Tichý, L., Rolocek, D., Zeleny, C. \& Chytry, M., 2007, New stopping rules for TWINSPAN, European Vegetation Survey, 16th Workshop, March 22-27, 2007.

Turner, T.R., Anapol, F. \& Jolly, C.J., 1997, 'Growth, development and sexual dimorphism in vervet monkeys (Cercopithecus aethiops) at four sites in Kenya', American Journal of Physical Anthropology 103, 19-35. http://dx.doi.org/10.1002/ (SICI)1096-8644(199705)103:1<19::AID-AJPA3>3.0.CO;2-8

Tchoukanski, I., 2010, ET Geo Wizards. Version 10.0 for ArcGIS, viewed on 13 June 2011, from http://www.ian-ko.com

Whiten, A., Byrne, R.W. \& Henzi, S.P., 1987, 'The behavioural ecology of mountain baboons', International Journal of Primatology 8, 367-388. http://dx.doi. org/10.1007/BF02737389

Whitten, P.L., 1983, 'Diet and dominance among female vervet monkeys (Cercopithecus aethiops)', American Journal of Primatology 5, 139-159. http:// dx.doi.org/10.1002/ajp.1350050205

Willems, E.P., 2009, 'From space to species: Integrating remotely sensed information on primary productivity into investigations and systems models of vervet monkey (Cercopithecus aethiops) socio-ecology', PhD thesis, Department of Anthropology, Durham University.

Willems, E.P. \& Hill, R.A., 2009, 'A critical assessment of two species distribution models: A case study of the vervet monkey (Cercopithecus aethiops)', Journal of Biogeography 36, 2300-2312. http://dx.doi.org/10.1111/j.13652699.2009.02166.x

Wolfheim, J.H., 1983, Primates of the world: Distribution, abundance and conservation, University of Washington Press, Seattle and London. 


\section{Appendix}

APPENDIX 1: Food species and plant parts consumed by vervet monkeys at Samara Game Reserve.

\begin{tabular}{|c|c|c|c|}
\hline Food species & Parts consumed & Number of scans & Percent intake \\
\hline Acacia karroo & Gum, seeds, flowers, leaves & 3159 & 33.80 \\
\hline Atriplex semibaccata R.Br. & Berries & 1543 & 15.33 \\
\hline Insects & - & 778 & 7.73 \\
\hline Lycium oxycarpum & Berries, leaves & 651 & 6.47 \\
\hline Schinus molle & Berries & 548 & 5.44 \\
\hline Lycium cinereum Thunb. & Berries, leaves, flowers & 475 & 4.72 \\
\hline Mesembryanthemaceae family & Leaves & 452 & 4.49 \\
\hline Helictotrichon turgidulum (Stapf) Schweick & Leaves & 304 & 3.02 \\
\hline Grewia robusta A. Cunn. & Berries, flowers & 243 & 2.41 \\
\hline Carissa bispinosa (L.) Desf. ex Brenan. & Berries & 194 & 1.93 \\
\hline Sceletium sp. & Leaves & 168 & 1.67 \\
\hline Rhus lancea & Berries & 150 & 1.49 \\
\hline Rhus longispina & Flowers & 145 & 1.44 \\
\hline Sansevieria sp. & Leaves & 86 & 0.85 \\
\hline Grasses (Cynodon incompletus; Panicum maximum) & Leaves & 84 & 0.83 \\
\hline Chenopodium sp. & Leaves & 74 & 0.74 \\
\hline Mesembryanthemaceae family & Leaves & 64 & 0.64 \\
\hline Diospyros lycioides De Winter & Berries, flowers, leaves & 46 & 0.46 \\
\hline Pentzia globosa Less. & Leaves & 21 & 0.21 \\
\hline Boscia albitrunca Gilg. \& Ben. & Berries & 20 & 0.20 \\
\hline Funghi & Mushrooms & 8 & 0.08 \\
\hline Portulacaria afra Jacq. & Leaves & 5 & 0.05 \\
\hline Cactus sp. & Leaves & 5 & 0.05 \\
\hline Gymnosporia buxifolia Szyszyl. & Berries & 1 & 0.01 \\
\hline Euclea crispa Thunb. & Leaves & 1 & 0.01 \\
\hline Aloe ferox Mill. & Flowers & 1 & 0.01 \\
\hline
\end{tabular}

